\title{
Influence of Leadership, Organizational Culture, Work Motivation, and Job Satisfaction of Performance Principles of Senior High School in Medan City
}

\author{
Syamsul Arif ${ }^{1}$, Zainudin ${ }^{2}$, Abdul Hamid K. ${ }^{3}$ \\ 1,2,3 Universitas Negeri Medan \\ syamsulariefsiregar@gmail.com
}

\begin{abstract}
This study aims to determine and examine the influence of Leadership $\left(X^{1}\right)$, Organizational Culture $\left(X^{2}\right)$, Work Motivation $\left(X^{3}\right)$, and Job Satisfaction $\left(X^{4}\right)$, on the Performance of High School Heads $\left(X^{5}\right)$ in Medan. This study also aims to determine the theoretical model of performance (fixed model) that can describe the structure of the causal relationship between the exogonus variable and the endogonus variable. This research was conducted in Medan City High School in 2017, with a total sample of 135 people. The research variable data selection uses a valid and reliable questionnaire based on the results of rational analysis (Expert Judgment) and instrument trials of 32 people from the study population. The data analysis technique used consisted of descriptive analysis, test requirements analysis, and path analysis with a significance level of $\alpha$ of 0.05 . The results of the analysis revealed Ho was rejected, Ha was accepted. So, there is a positive and significant direct influence of Leadership, Organizational Culture, Work Motivation, and Job Satisfaction on the Performance of High School Heads in Medan City.
\end{abstract}

Keywords: Leadership; organizational culture; work motivation; job satisfaction; performance

\section{Introduction}

The school principal as manager of the education unit in the school he leads plays a very strategic role because he is responsible for administering all the components and systems of the school. The principal must have a number of competencies in order to fulfill the principal's principal duties. This is in accordance with Minister of National Education Regulation No. 13 of 2007 which stipulates that there are five standard competencies that must be possessed by school principals/madrasah, namely: (a) personality, (b) managerial, (c) entrepreneurship, (d) supervision, and (e) social. In particular, the principal's managerial competence must be an important concern and be well managed, including knowledge about management (Surya Dharma 2008: 9). According to Edy Sutrisno (2009: 231) Leadership is a process of one's activities to move others by leading, guiding, and influencing others, to do something in order to achieve the expected results.

Exploring the results of research related to performance, Ishag, Yusrizal, and Bahrun found that the leadership of the school had a direct positive effect on the performance of teachers of Public Senior High School 3 and Public Senior High School 4 Meulaboh. Siburian found organizational culture, innovative behavior, job satisfaction; work motivation had a positive direct effect on the performance of SMK heads in Medan. Relevant to this, Titik Handayani, Aliyah A. Rasyid found the school principal's leadership had a direct positive effect on teacher motivation and the performance of high school teachers in Wonosobo. Ali Nazim, Ali Shahid, Ahsan Anjum, Rahman Wali, and Kakakhel Jan Shahid found leadership styles to influence job satisfaction. Furthermore, Syakir and Pardjono found in their research that the principal's leadership, work motivation, and organizational culture had a direct positive effect on competence. 
Based on the results of research that has been revealed can be synthesized that endogenous variables affect exogenous variables. Paying attention to the Strategic Plan in the Ministry of Education and Culture's Long-Term Development Plan (RPJP) in 2025 which targets the ratio between the number of high schools and vocational schools to reach $30 \%$ : $70 \%$, to address this the Head of the North Sumatra Provincial Education Office in the 20102014 Strategic Plan formulated the vision, "Realizing North Sumatra's community education system that is competitive and of good character."One of the missions that were formulated to realize this vision," increased the professionalism of educators and education staff ". Increasing the professionalism of high school principals is included in the mission. This implicitly shows the importance of a study focusing on the behavior of high school principals in particular.

The description above shows that there are various factors that affect performance, both those found based on the results of research or based on theoretical explanations. In addition, the description above also shows the gap between the expected performance and the performance of the head of high school in Medan at present. Therefore, to improve the performance of high school principals in Medan can be done through research on the development of theoretical performance models. As explained above, that performance is influenced by various factors, including: leadership, organizational culture, motivation, job satisfaction, and work motivation. For this reason, research needs to be conducted on the Effects of Leadership, Organizational Culture, Work Motivation, and Job Satisfaction, on the Performance of High School Heads in Medan City.

\section{Review of Literature}

Wirawan (2009: 5) argues that performance is the output produced by the functions or indicators of a job or a profession within a certain time. Based on the integration model of Jason A, Colquit, at. all., it can be seen that performance is the estuary and organizational culture is the base, while work motivation, job satisfaction is between the beginning and end. The meaning of the beginning and the end meant is that the initial variable influences the final variable, while the variable between the beginning and end is the interpending variable. Performance can be achieved well if the principal performs the main tasks, functions, and responsibilities have the ability or competence in leadership.

Leadership can be defined as a process of directing and giving influence to the activities of a group of members who are related to their duties (Stoner, 1992: 114). According to Gorton et al., Leadership is a characteristic of leaders in influencing subordinates to achieve organizational goals. The success of leadership is partly determined by the ability of leaders to develop their organizational culture.

Mangkunegara (2005: 113) states that organizational culture is a set of assumptions or systems of beliefs, values, and norms developed in organizations that serve as guidelines for behavior for its members to overcome the problem of external and internal adaptation. Organizational culture is a pattern of beliefs and organizational values that are believed and imbued by all members in doing work as an appropriate way to understand, think, and feel about related problems, so that it will become a value or rule within the organization. This will encourage members of the organization to work harder and create work motivation. 
Motivation is as a series of giving encouragement to someone to carry out actions to achieve the desired goals Sondang (1999: 13) ,. Motivation will cause impetus to someone who causes him to do certain actions to meet their needs. So work motivation is a psychological condition that encourages workers to make an effort to produce goods or services so that a goal can be achieved.

Job satisfaction is the attitude that someone shows in feeling his job. According to Colquitt, Lepine, and Wesson (2009: 105) job satisfaction is "as a pleasurable emotional state resulting from the appraisal of one's job or job experiences". Job satisfaction will create a feeling that supports / does not support the employee who is related to his work or with his condition.

\subsection{Theoretical Framework}

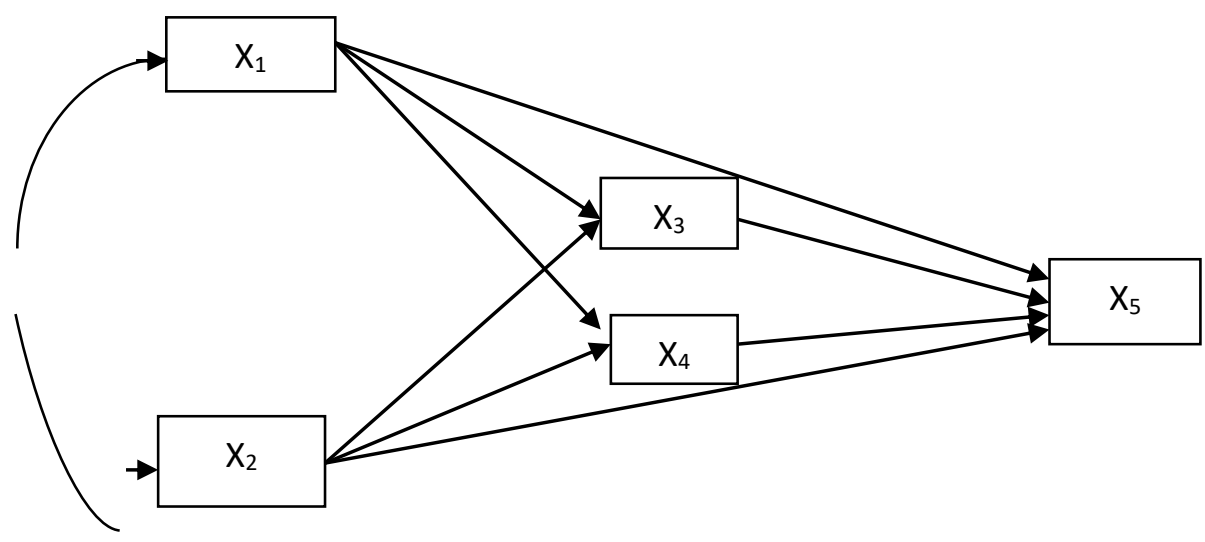

Leadership $\left(\mathrm{X}^{1}\right)$ has a direct influence on work motivation $\left(\mathrm{X}^{3}\right)$. The leadership itself arouses work motivation towards the leader and also subordinates. If the leadership intended is a school organization, namely a high school in the city of Medan, then the leadership affects the work motivation. In line with this, it is suspected that leadership has a positive effect on the work motivation of high school principals in Medan.

Leadership $\left(\mathrm{X}^{1}\right)$ has a direct influence on job satisfaction $\left(\mathrm{X}^{4}\right)$. The success of an organization in achieving its goals, for a leader is to be its own satisfaction. If the leadership in question is a school organization that is a high school in Medan, then the leadership has a direct effect on job satisfaction. In line with this description, it is suspected that leadership has a direct effect on job satisfaction of high school principals in Medan.

Organizational culture $\left(\mathrm{X}^{2}\right)$ has a direct influence on work motivation $\left(\mathrm{X}^{3}\right)$. Organizational culture will generate work impulse, the pleasure of using time in work so as to use sufficient work time, even beyond what is often called overtime. In line with this, it is suspected that Organizational Culture has a direct positive effect on the work motivation of high school principals in Medan

Organizational culture $\left(\mathrm{X}^{2}\right)$ has a direct influence on job satisfaction $\left(\mathrm{X}^{4}\right)$. The organizational culture in a school institution will be the basis for the satisfaction of the principal, teachers, and education staff, as well as students. Organizational culture provides comfort because the habits that have been adopted in the organization can take place so that it affects job satisfaction. The description shows that organizational culture is suspected to have a direct positive effect on job satisfaction. 
Leadership $\left(\mathrm{X}^{1}\right)$ has a direct influence on performance $\left(\mathrm{X}^{5}\right)$. The performance of teachers, education personnel and students is inseparable from the performance of the school principal. In line with this, the principal's leadership becomes a variable that greatly affects the performance of all human resources in the school. Likewise, the head of a high school in Medan, that his leadership affects his performance. Based on the description that has been presented, it can be synthesized that leadership is suspected to have a direct positive effect on the performance of high school principals in Medan.

Organizational culture $\left(\mathrm{X}^{2}\right)$ has a direct influence on performance $\left(\mathrm{X}^{5}\right)$. The stronger the organizational culture the principal has, the better the performance. The performance of the principal is influenced by the strength of the organizational culture of the principal. The same thing happened to the head of high school in Medan, that the stronger the organizational culture that is owned, the better the performance. Based on the descriptions that have been presented, it can be synthesized that it is suspected that organizational culture has a direct positive influence on the performance of high school principals in Medan.

Work motivation $\left(\mathrm{X}^{3}\right)$ has a direct effect on performance $\left(\mathrm{X}^{5}\right)$. The organization where an individual works is expected to be able to support and understand their motivation for the realization of a goal at work. If the principal has a very high desire to work well to achieve school goals, then the performance will be better. In line with this, the higher the work motivation possessed by the principal, the better the performance. Based on the description above, it is suspected that work motivation has a direct effect on the performance of high school principals.

Job satisfaction $\left(\mathrm{X}^{4}\right)$ has a direct effect on performance $\left(\mathrm{X}^{5}\right)$. The higher job satisfaction means that it will make someone stronger in his belief that he has good ability to complete his work. If this is related to the performance of the principal (high school), then his performance will be better if he gets the results as expected from his work. Based on the description above, it can be synthesized that it is suspected that job satisfaction has a direct positive effect on the performance of high school principals in Medan.

\subsection{Research Hypothesis}

Based on the study of the theory and framework of thought proposed, the following research hypotheses are formulated:

1. Leadership has a positive direct effect on the Work Motivation of High School Heads in Medan.

2. Leadership has a direct positive effect on the Job Satisfaction of Head of Senior High Schools in Medan.

3. Organizational Culture has a positive direct effect on the Work Motivation of High School Heads in Medan City.

4. Organizational Culture has a positive direct effect on the Job Satisfaction of High School Heads in Medan City.

5. Leadership has a direct positive effect on the performance of high school principals in Medan.

6. Organizational Culture has a positive influence on the Performance of High School Heads in Medan City.

7. Work Motivation Has a Positive Direct Effect on the Performance of High School Heads in Medan City. 
8. Job Satisfaction has a Positive Direct Impact on the Performance of SMA Heads in Medan City.

\section{Research Method}

This type of research is included in ex post facto research. The population of this research is all the head of Medan's Public / Private High Schools who have been at least 2 (two) years, of which 191 people are present, namely 21 heads of state high schools and 170 heads of private high schools based on the High School Principal Data, City government census results Medan in 2017. The number of samples selected became 135. Data collection techniques used in this study was surveys in the field by distributing questionnaires to the principal who was used as the research sample. The data analysis technique was performed using SPSS version 20 computer aids in two stages namely descriptive and inferential.

\section{Result}

\subsection{Description of Research Variables}

a. Frequency Distribution of Research Variable Data

Description of the data presented in this section includes data on Leadership $\left(\mathrm{X}^{1}\right)$, Organizational Culture $\left(\mathrm{X}^{2}\right)$, Work Motivation $\left(\mathrm{X}^{3}\right)$, Job Satisfaction $\left(\mathrm{X}^{4}\right)$, and Performance $\left(\mathrm{X}^{5}\right)$ from Head of High Schools in Medan. A description of the research variable data is presented in the summary of the results of the descriptive analysis in Table 1 below.

Table 1. Description of Statistics

Statistics

\begin{tabular}{|c|c|c|c|c|c|c|}
\hline & Leadership & & $\begin{array}{l}\text { Organizational } \\
\text { Culture }\end{array}$ & $\begin{array}{c}\text { Work } \\
\text { Motivation }\end{array}$ & $\begin{array}{c}\text { Job } \\
\text { satisfaction }\end{array}$ & $\begin{array}{c}\text { The } \\
\text { performance }\end{array}$ \\
\hline \multirow{2}{*}{$\mathrm{N}$} & Valid & 135 & 135 & 135 & 135 & 135 \\
\hline & Missing & 0 & 0 & 0 & 0 & 0 \\
\hline \multicolumn{2}{|c|}{ Mean } & 125,4889 & 70,1481 & 73,0593 & 64,3481 & 117,8593 \\
\hline \multicolumn{2}{|c|}{ Std. Error of Mean } & 2,51494 & ,98437 &, 88040 &, 75489 & 2,53325 \\
\hline \multicolumn{2}{|c|}{ Median } & 126,0000 & 71,0000 & 73,0000 & 64,0000 & 120,0000 \\
\hline \multicolumn{2}{|c|}{ Mode } & $126,00^{\mathrm{a}}$ & 70,00 & 80,00 & 70,00 & $120,00^{\mathrm{a}}$ \\
\hline \multicolumn{2}{|c|}{ Std. Deviation } & 29,22095 & 11,43738 & 10,22928 & 8,77098 & 29,43375 \\
\hline \multicolumn{2}{|c|}{ Variance } & 853,864 & 130,814 & 104,638 & 76,930 & 866,346 \\
\hline \multicolumn{2}{|c|}{ Skewness } &,- 289 &,- 503 &,- 501 &,- 145 &,- 057 \\
\hline \multicolumn{2}{|c|}{ Std. Error of Skewness } & ,209 & ,209 & ,209 & ,209 &, 209 \\
\hline \multicolumn{2}{|c|}{ Range } & 113,00 & 49,00 & 44,00 & 45,00 & 116,00 \\
\hline \multicolumn{2}{|c|}{ Minimum } & 62,00 & 41,00 & 47,00 & 40,00 & 60,00 \\
\hline \multicolumn{2}{|c|}{ Maximum } & 175,00 & 90,00 & 91,00 & 85,00 & 176,00 \\
\hline \multicolumn{2}{|c|}{ Sum } & 16941,00 & 9470,00 & 9863,00 & 8687,00 & 15911,00 \\
\hline \multirow{3}{*}{$\begin{array}{l}\text { Perce } \\
\text { ntiles }\end{array}$} & 25 & 106,0000 & 62,0000 & 68,0000 & 58,0000 & 94,0000 \\
\hline & 50 & 126,0000 & 71,0000 & 73,0000 & 64,0000 & 120,0000 \\
\hline & 75 & 148,0000 & 79,0000 & 81,0000 & 71,0000 & 138,0000 \\
\hline
\end{tabular}

a. Multiple modes exist. The smallest value is shown 
Based on table 1 about the statistical description, it can be seen the characteristics of the Leadership variables which include a maximum score of 75 , a minimum score of 62 , a mean of 125 , and a standard deviation of 29.22. The maximum score does not reach the ideal maximum score of 76 , and also the minimum score is not lower than the ideal minimum score of 44 .

\subsection{Description of Leadership Variable $\left(\mathrm{X}^{1}\right)$}

Table 2. Frequency Distribution of Leadership Scores $\left(\mathrm{X}^{1}\right)$

\begin{tabular}{cccc} 
Class & Interval Class & Absolute Frequency & Cumulative Frequency (\%) \\
\hline 1 & Under -35 & 0 & 0,00 \\
\hline 2 & $36-65$ & 5 & 3,70 \\
\hline 3 & $66-95$ & 16 & 15,56 \\
\hline 4 & $96-125$ & 43 & 47,41 \\
\hline 5 & $126-155$ & 44 & 80,00 \\
\hline 6 & $156-185$ & 27 & 100,00 \\
\hline 7 & $186-$ Up & 0 & 100,00 \\
\hline & Total & 135 & 100,00
\end{tabular}

Note:

Average $=125.4=125$ (rounding)

$\mathrm{SD}=29.22=29$ (rounding)

The distribution of Leadership variable data can be seen from table 2, namely as many as 44 people in the 126 -155 range and as many as 43 people in the 96-125 range, and as many as 27 people in the 156-185 range, as many as 16 people in the 66-95 range, and as many as 5 people in the range 36-65. This shows the highest amount of data distribution in grades 5 and 4 .

Table 3. Trend of Leadership Variable Data

\begin{tabular}{ccccl} 
No. & Span & Observation Frequency & Percentage $\mathbf{\%})$ & Tendency Category \\
\hline 1 & Under -76 & 10 & 7,4 & Poorly \\
\hline 2 & $77-110$ & 29 & 21,48 & Not good \\
\hline 3 & $111-144$ & 58 & 42,96 & Passably \\
\hline 4 & $145-$ Up & 38 & 28,16 & Good \\
\hline & Total & 135 & 100 &
\end{tabular}

Based on Table 3 it can be seen that the tendency of Leadership Variables is quite good as much as $42.96 \%$, and followed by good as much as $28.16 \%$, not as good as much as $21.48 \%$, and there are still not as good as $7.4 \%$. Leadership of high school principals in Medan City was not in line with expectations, because there were still as many as $28.88 \%$ which were not good and not good. There is a problem with senior high school leadership in Medan, and the lowest indicators that contribute to the problem must be analyzed.

Table 4. Descriptions of Mean Leadership Indicator Scores

\begin{tabular}{clc} 
No & \multicolumn{1}{c}{ Indicator } & Average Score \\
\hline 1 & Building Organizational Culture & 3,38 \\
\hline 2 & $\begin{array}{l}\text { Organizing resources, which include: building organizational } \\
\text { structure, authority and responsibility, mapping the }\end{array}$ & 3,06
\end{tabular}


characteristics of human resources and material / financial resources

\begin{tabular}{lll}
\hline 3 & Mobilize resources with a variety of strategies & 2,49 \\
\hline 4 & managing information and administration & 2,54 \\
\hline 5 & delegate authority and duties & 2,64 \\
\hline 6 & $\begin{array}{l}\text { controlling the organization which includes evaluation and } \\
\text { supervision, }\end{array}$ & 2,44 \\
\hline 7 & give protection to subordinates & 2,93
\end{tabular}

Based on table 4, the average score description table for Leadership indicators can be seen, that the indicators controlling the organization which includes evaluation and supervision are the biggest causes of Leadership problems with a mean score of 2.44, followed by indicators Mobilizing resources with various strategies with a mean score of 2 , 54 , followed by indicators of managing information and administration as well as indicators of delegating authority and duties.

\subsection{Deskripsi Variabel Budaya Organisasi $\left(\mathrm{X}^{2}\right)$}

Table 5. Frequency Distribution of Organizational Culture Scores $\left(X^{2}\right)$

\begin{tabular}{cccc} 
Class & Interval Class & Absolute Frequency & Cumulative Frequency (\%) \\
\hline 1 & Under -34 & 0 & 0 \\
\hline 2 & $35-46$ & 4 & 3 \\
\hline 3 & $47-58$ & 20 & 17,78 \\
\hline 4 & $59-70$ & 38 & 45,93 \\
\hline 5 & $71-82$ & 53 & 85,19 \\
\hline 6 & $83-94$ & 20 & 100 \\
\hline 7 & $95-$ Up & 0 & 100 \\
\hline & Total & 135 & 100
\end{tabular}

Note:

$$
\begin{aligned}
& \text { Average }=70,15=70 \text { (rounding) } \\
& \mathrm{SD}=11.44=11 \text { (rounding up) }
\end{aligned}
$$

The distribution of Leadership variable data can be seen from table 5, namely as many as 53 people in the range 71-82 and as many as 38 people in the range 59-70, and as many as 20 people in the range $83-94$, as many as 20 people in the range $47-58$, and as many as 4 people in the range $35-46$. This shows the highest amount of data distribution in grades 5 and 4.

Table 6. Trends in Organizational Culture Variable Data

\begin{tabular}{lcccc} 
No. & Span & Frekuensi Observasi & Percentage $(\%)$ & Tendency Category \\
\hline 1 & Under- 44 & 3 & 2,22 & Not strong \\
\hline 2 & $45-65$ & 40 & 29,63 & Not Strong enough \\
\hline 3 & $66-86$ & 86 & 63,70 & Strong enough \\
\hline 4 & $87-$ Up & 6 & 4,44 & Strong \\
\hline & Total & & 100 &
\end{tabular}

Based on table 6, the tendency of Organizational Culture variables owned by high school principals in Medan tends to be strong, as many as $63.7 \%$ and less strong as much as $29.63 \%$ and not as strong as 2.22\%; and there are only $4.44 \%$ who have a strong 
Organizational Culture. There is a problem of the Organizational Culture of the Principals, because as many as $31.85 \%$ of those who have an Organizational Culture are not strong and less strong.

Table 7. Descriptions of Mean Scores of Organizational Culture Indicators

\begin{tabular}{clc} 
No. & \multicolumn{1}{c}{ Indicator } & Average Score \\
\hline 1. & Risk taking & 2,16 \\
\hline 2. & Attention to detail & 1,85 \\
\hline 3. & Results orientation & 3,04 \\
\hline 4. & People orientation & 3,01 \\
\hline 5. & Team orientation & 2,80 \\
\hline 6. & Aggressiveness & 1,89 \\
\hline 7. & Stability & 3,06
\end{tabular}

\subsection{Description of Work Motivation Variables $\left(X^{3}\right)$}

Table 8. Frequency Distribution of Work Motivation Scores $\left(X^{3}\right)$

\begin{tabular}{cccc} 
Class & Interval Class & Absolute Frequency & Cumulative Frequency (\%) \\
\hline 1 & Under -40 & 0 & 0 \\
\hline 2 & $41-51$ & 6 & 4,44 \\
\hline 3 & $52-62$ & 13 & 14,07 \\
\hline 4 & $63-73$ & 50 & 51,11 \\
\hline 5 & $74-84$ & 46 & 85,19 \\
\hline 6 & $85-95$ & 20 & 100 \\
\hline 7 & $96-$ Up & 0 & 100 \\
\hline & Total & 135 & 100
\end{tabular}

Note:

Average $=73.06=73$ (rounding up)

$\mathrm{SD}=10.23=10$ (rounding up)

The distribution of Leadership variable data can be seen from table 8, namely as many as 50 people in the range 63-73 and as many as 46 people in the range $74-84$, and as many as 20 people in the 85-95 range, as many as 13 people in the 52-62 range, and as many as 6 people in the range 41-51. It shows the highest amount of data distribution in grades 4 and 5.

Table 9. Trends in Work Motivation Variable Data

\begin{tabular}{ccccc} 
No. & Span & Observation Frequency & Percentage $(\%)$ & Tendency Category \\
\hline 1 & Under -44 & 0 & 0,00 & Low \\
\hline 2 & $45-65$ & 26 & 19,26 & Low enough \\
\hline 3 & $66-86$ & 100 & 74,07 & High enough \\
\hline 4 & $87-$ Up & 9 & 6,67 & High \\
\hline & Total & 135 & 100 &
\end{tabular}

Based on table 4.9. It can be seen that Work Motivation tends to be quite high, as many as 100 people or $74.07 \%$, followed by quite low as many as 26 people or $19.26 \%$, and there are only 9 people or $6.67 \%$ who have High Work Motivation, and none have low motivation. All school principals should have high Work Motivation, but in reality only $19.26 \%$ have high Work Motivation. 
Table 10. Trends in Work Motivation Variable Data

\begin{tabular}{clc} 
No. & \multicolumn{1}{c}{ Indicator } & Average Score \\
\hline 1. & $\begin{array}{l}\text { The amount of time and effort to carry out the duties and responsibilities } \\
\text { with the highest achievements. }\end{array}$ & 1,96 \\
\hline 2. & Have a happy feeling at work and praise from the work. & 3,09 \\
\hline 3. & Honor and breadth of association vertically and horizontally. & 3,37 \\
\hline 4. & Feelings of pleasure as a source of information and work knowledge. & 2,04 \\
\hline 5. & $\begin{array}{l}\text { Feelings of pleasure at the highest position in the organizational } \\
\text { structure and society. }\end{array}$ & 3,14 \\
\hline 6 & Happy to control with reward and punishment. & 3,29
\end{tabular}

Based on table 10 it can be seen that the indicator of the amount of time and effort to carry out tasks and responsibilities with the highest achievements is the most important cause of work motivation problems, and is followed by indicators of feeling happy as a source of information and work knowledge, with each average score of 196 and 2.04. Other indicators are good enough because the average score is greater than 3 .

\subsection{Job Satisfaction Variable Description $\left(\mathrm{X}^{4}\right)$}

Table 11. Frequency Distribution of Job Satisfaction Scores $\left(X^{4}\right)$

\begin{tabular}{cccc} 
Class & Interval Class & Absolute Frequency & Cumulative Frequency (\%) \\
\hline 1 & Under -23 & 0 & 0 \\
\hline 2 & $24-43$ & 2 & 1,48 \\
\hline 3 & $44-53$ & 14 & 11,85 \\
\hline 4 & $54-63$ & 47 & 46,67 \\
\hline 5 & $64-73$ & 53 & 85,93 \\
\hline 6 & $74-83$ & 17 & 98,52 \\
\hline 7 & $84-$ Up & 2 & 100 \\
\hline & Total & 135 & 100
\end{tabular}

Note:

Average $=64.35=64$ (Rounding)

$\mathrm{SD}=8.77=9$ (rounding up)

The distribution of Leadership variable data can be seen from table 11, namely as many as 53 people in the range of 64-73 and as many as 47 people in the range 54-63, and as many as 17 people in the range 74-83, as many as 2 people each in the range $24-43$ and 84 and above. This shows the highest amount of data distribution in grades 5 and 4 .

Table 12. Data trends on Job Satisfaction Variables

\begin{tabular}{ccccc} 
No. & Span & Observation Frequency & Percentage $(\%)$ & Tendency Category \\
\hline 1 & Under -43 & 2 & 1,48 & Not satisfied \\
\hline 2 & $44-63$ & 61 & 45,19 & Less satisfied \\
\hline 3 & $64-83$ & 70 & 51,85 & Satisfied enough \\
\hline 4 & $84-$ Up & 2 & 1,48 & Satisfied \\
\hline & Total & 135 & 100 &
\end{tabular}

Trends in Job Satisfaction of SMA principals in Medan based on table 4.12. are quite satisfied as many as 70 people or $51.85 \%$ and followed by the dissatisfied category as many 
as 61 people or $45.19 \%$. There are only 2 people each or $1.48 \%$ who are satisfied or dissatisfied with the position of the school principal they lead. Ideally, as school leaders, principals must have satisfaction, but because this is not the case there are still problems that arise.

Table 13. Descriptions of Mean Work Satisfaction Score Scores

\begin{tabular}{clc} 
No. & \multicolumn{1}{c}{ Indicator } & Average Score \\
\hline 1. & Promotion opportunities & 1,91 \\
\hline 2. & Work itself & 3,00 \\
\hline 3. & Salary & 2,73 \\
\hline 4. & Co-workers & 2,76 \\
\hline 5. & Supervision & 2,8
\end{tabular}

Based on table 13 it can be seen that the promotion opportunity indicator is the main contributor to the problem, which is indicated by the average score of 1.91 ; followed by indicators of salary, coworkers, and supervision with an average score of 2.73 and 2.76, and 2.8 , respectively.

\subsection{Description of Performance Variable $\left(\mathrm{X}^{\mathbf{5}}\right)$}

Table 14. Frequency Distribution of Performance Scores $\left(\mathrm{X}^{5}\right)$

\begin{tabular}{cccc} 
Class & Interval Class & Absolute Frequency & Cumulative Frequency (\%) \\
\hline 1 & Under -28 & 0 & 0 \\
\hline 2 & $29-58$ & 0 & 0 \\
\hline 3 & $59-88$ & 28 & 20,74 \\
\hline 4 & $89-118$ & 35 & 46,67 \\
\hline 5 & $119-148$ & 52 & 85,19 \\
\hline 6 & $149-178$ & 20 & 100 \\
\hline 7 & $179-$ Up & 0 & 100 \\
\hline & Total & 135 & 100
\end{tabular}

Average $=117.86=118$ (rounding up)

$\mathrm{SD}=29.44=29$ (rounding up).

The distribution of Performance variable data can be seen from table 14, which is as many as 52 people in the range 119 - 148 and as many as 35 people in the range $89-118$, and as many as 28 people in the range $59-88$, as many as 20 people in the range $149-178$. it shows the highest amount of data distribution in grades 5 and 4.

Table 15. Trends in Performance variable data

\begin{tabular}{ccccc} 
No. & Span & Observation Frequency & Percentage $(\%)$ & Tendency Category \\
\hline 1 & Under -86 & 28 & 20,74 & Low \\
\hline 2 & $87-125$ & 49 & 36,30 & Low enough \\
\hline 3 & $126-164$ & 50 & 37,03 & High enough \\
\hline 4 & $165-$ Up & 8 & 5,93 & High \\
\hline & Total & 135 & 100 &
\end{tabular}

Next table 15 shows the trend of Performance variable data. Based on the table it can be seen that the tendency of high school principals' performance in Medan is quite high and followed by quite low, with 50 people each or $37.03 \%$ and 49 people or $36.3 \%$. There were only 8 people $(5.93 \%)$ of the principals who had high performance, but there were 28 people 
(20.74\%) whose performance was low. This shows the existence of performance problems, and by looking at the indicators that build performance in table 4.16., The biggest indicators contributing to the problem are planning and implementing school programs and activities that are in accordance with the school strategic plan and implementing the learning process, each of which has a mean score of 1, 48 and 1.53.

Table 16. Descriptions of Average Performance Indicator Scores

\begin{tabular}{|c|l|c|}
\hline No & \multicolumn{1}{|c|}{ Indicator } & Average Score \\
\hline 1 & Learning Plan & 2,83 \\
\hline 2. & Carry out the learning process & 1,53 \\
\hline 3. & Carry out evaluation of learning & 2,88 \\
\hline 4. & Formulate the school strategic plan (Renstra) & 2,51 \\
\hline \multirow{2}{*}{5} & $\begin{array}{l}\text { Plan and implement school programs and activities in accordance } \\
\text { with the school strategic plan }\end{array}$ & 1,48 \\
\hline \multirow{2}{*}{6.} & Empower school education resources: & 2,75 \\
\cline { 2 - 3 } & Teacher & 2,56 \\
\cline { 2 - 3 } & Educational Personnel & 2,45 \\
\cline { 2 - 3 } & Facilities and infrastructure & 2,62 \\
\cline { 2 - 3 } & Funds / finance & 2,90 \\
\hline \multirow{2}{*}{7.} & $\begin{array}{l}\text { Make reports and accountability for school programs and } \\
\text { activities }\end{array}$ & 2,92 \\
\hline 8. & Plan and implement cooperation with the community. & 2,57 \\
\hline
\end{tabular}

Based on the results of testing the first hypothesis to the eighth hypothesis, the empirical model of this study is shown in the following figure.

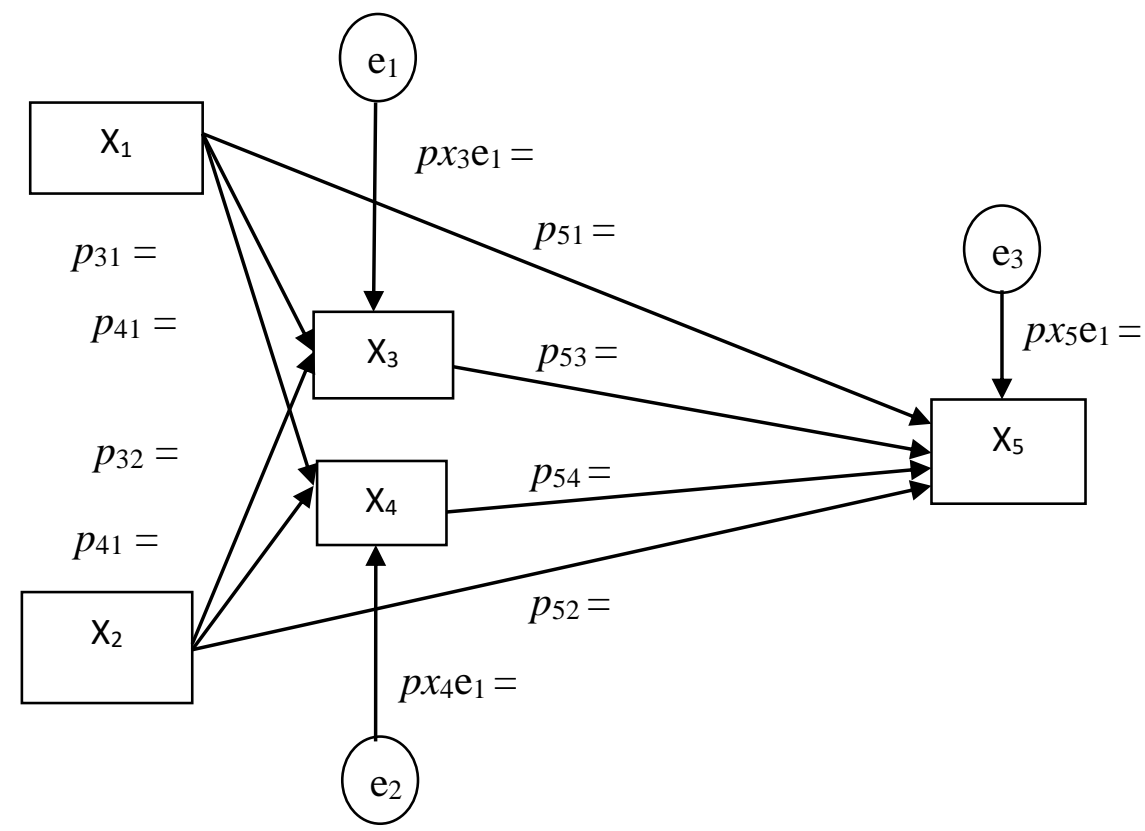




\section{Discussion}

The results of the study, based on the highest percentage, revealed that high school principals in Medan had high performance (1) high enough 37.03\% (50 people), (2) low enough $36.3 \%$ (49 people), (3) low 20, $74 \%$ (28 people), and (4) high $5.93 \%$ ( 8 people). The performance is not yet in line with expectations so it must be improved and improved. The improvement in the performance of senior high school principals in Medan is mainly on indicators of planning and implementing school programs and activities that are in accordance with the school strategic plan and also implementing the learning process.

Hypothesis testing shows that the variables of Leadership, Organizational Culture, Work Motivation, and Job Satisfaction directly influence Performance. The results of the study are in line with the integration model of Colquitt, Levina, Wesson, which states that Work Motivation and Job Satisfaction that are in the order of individual mechanisms directly influence Performance. However, in the organizational mechanism, the variables of Leadership and Organizational Culture do not have a direct effect. However, according to Mathis, Leadership and Organizational Culture directly influence Performance, in accordance with the results of this study. The theories and models of Colquitt, Levine, and Wesson with Mathis theories and models are complementary and undisputed in this study. If it is expected that the performance of senior high school principals in Medan increases in line with expectations, the indicators that build performance must be improved, especially those with low performance. The same indicators that build the variables of Leadership, Organizational Culture, Work Motivation, and Job Satisfaction, must be increased so that they reach the maximum.

Work Motivation Variables and Job Satisfaction Variables according to Colquitt et al. and Mathis has a direct effect on performance, the tendency must be questioned. Work Motivation tends to be quite high, as many as 100 people or $74.07 \%$, and followed quite low as many as 26 people or $19.26 \%$, and there are only 9 people or $6.67 \%$ who have high Work Motivation, and no one has low motivation. All school principals should have high work motivation, but in reality only $19.26 \%$ have high work motivation. Indicator of Work Motivation variable apparently has not yet reached the highest ideal score. That is, indicators that build Work Motivation must be improved, especially indicators of the amount of time and effort to carry out tasks and responsibilities with the highest achievements and indicators of feeling happy as a source of work information and knowledge. All school principals should have high work motivation, but in reality only $19.26 \%$ have high work motivation. Indicator of Work Motivation variable apparently has not yet reached the highest ideal score. That is, indicators that build Work Motivation must be improved, especially indicators of the amount of time and effort to carry out tasks and responsibilities with the highest achievements and indicators of feeling happy as a source of work information and knowledge.

The direct proportional effect of Leadership $\left(X^{1}\right)$ on Performance $\left(X^{5}\right)$ is $11.56 \%$. The indirect effect of proportional leadership $\left(\mathrm{X}^{1}\right)$ on performance $\left(\mathrm{X}^{5}\right)$ through work motivation $\left(\mathrm{X}^{3}\right)$ is $3.28 \%$. The indirect effect of proportional leadership $\left(\mathrm{X}^{1}\right)$ on performance $\left(\mathrm{X}^{5}\right)$ through job satisfaction $\left(\mathrm{X}^{4}\right)$ is $4.71 \%$. The proportional direct effect of Organizational Culture $\left(\mathrm{X}^{2}\right)$ on Performance $\left(\mathrm{X}^{5}\right)$ is $4.54 \%$. The indirect influence of proportional Organizational Culture $\left(X^{2}\right)$ on Performance $\left(X^{5}\right)$ through Job Satisfaction $\left(X^{4}\right)$ is $2.41 \%$. The 
indirect proportional effect of Organizational Culture $\left(\mathrm{X}^{2}\right)$ on Performance $\left(\mathrm{X}^{5}\right)$ through Work Motivation $\left(\mathrm{X}^{3}\right)$ is $2.95 \%$. The proportional direct effect of Work Motivation $\left(\mathrm{X}^{3}\right)$ on Performance $\left(\mathrm{X}^{5}\right)$ is $6.81 \%$. Indirectly proportional influence of Work Motivation $\left(\mathrm{X}^{3}\right)$ on Performance $\left(\mathrm{X}^{5}\right)$ through the superious path of $7.17 \%$ (rounding). The proportional direct effect of Job Satisfaction $\left(X^{4}\right)$ on Performance $\left(X^{5}\right)$ is $9.36 \%$. The indirect effect of proportional job satisfaction $\left(X^{4}\right)$ on performance $\left(X^{5}\right)$ through superiors' channels is $9.35 \%$. This study also found direct effects of other variables besides Leadership $\left(X^{1}\right)$, Organizational Culture $\left(\mathrm{X}^{2}\right)$, Work Motivation $\left(\mathrm{X}^{3}\right)$, and Job Satisfaction $\left(\mathrm{X}^{4}\right)$ of $28.62 \%$. In line with this, for further research need to multiply variables that affect performance.

\section{Conclusion}

Based on the results of hypothesis testing, it was concluded that:

1. Senior High School Leadership in Medan has a significant direct effect on work motivation,

2. The Organizational Culture of the Head of Senior High School in Medan has a significant direct effect on his work motivation,

3. The leadership of the head of high school in Medan has a significant direct effect on job satisfaction,

4. The organizational culture of high school principals in Medan has a significant direct effect on job satisfaction,

5. The leadership of senior high school Principals in Medan has a significant direct effect on their performance,

6. The Organizational Culture of High School Heads in Medan City has a significant direct effect on their performance,

7. The work motivation of high school principals in Medan has a significant direct effect on their performance,

8. Job Satisfaction The head of a high school in Medan has a significant direct effect on its performance.

\subsection{Implication Review}

\section{a. Theoretical Implications}

The results showed that the exogonus and endogonus variables have a causal relationship, namely Leadership and Organizational Culture as an exogonus variable significantly influence work motivation as an endogonus variable. The exogonus and endogonus variables have a causal relationship, namely Leadership and Organizational Culture as an exogonus variable that has a significant direct effect on Job Satisfaction as an endogonus variable. This explains that the exogonus variable of Leadership and Organizational Culture is the initial variable that causes changes in Job Satisfaction. The results of the study conclude that the theory has not been refuted and is still valid. The theory of the integration model of organizational behavior from Colcuitt, Lepine, and Wesson which states that Leadership and Organizational Culture have an indirect effect on Performance through Work Motivation and Job Satisfaction are proven true in this study.

In accordance with the theories under study, which build the research hypothesis, which includes the theory of the Organizational Behavior Integration Model of Colquitt, Lepine, and 
Wesson, states that Work Motivation and Job Satisfaction directly influence work motivation. The results of this study conclude that the theory has not been refuted and is still valid.

Based on the results of this study, which still maintains the truth of the theories of Colquitt, Lepine, and Wesson, as well as the theories of Mathis, Robert, and Jackson, the variables of Leadership, Organizational Culture, Work Motivation, and Job Satisfaction determine changes in performance variables. These theories explain many variables that affect Work Motivation, Job Satisfaction, and Performance, and this research proves the truth of the theory.

\section{b Practical Implications}

- Practical Implications for Researchers

Leadership Variables, Organizational Culture, Work Motivation, and Job Satisfaction are important variables and determine changes in the performance of high school principals in Medan. Although the four influential variables have been studied, and the magnitude of each influence is directly proportional to the performance, there are still many other variables that affect the performance and influence of $28.62 \%$. In line with this, the researchers had the opportunity to study and find these variables for the sake of completeness of the variables influencing performance.

\section{- Practical Implications for High School Principals}

This research shows that the performance of school principals has not been satisfactory, it still tends to be quite good and not good, so that school principals must be aware of this in order to improve their competencies and abilities as quality principals. In general, all indicators that build performance variables must be improved, especially for the most problematic variable indicators, namely planning and implementing school programs and activities that are in accordance with the school strategic plan and implementing the learning process. The principal must improve his leadership through improving all indicators that build leadership, especially indicators controlling the organization which includes evaluation and supervision, mobilizing resources with various strategies, managing information and administration, and delegating authority and tasks.

\section{- Practical Implications for the Head of the Education Office}

As is known from the results of this study, the overall variables studied still tend to be in the sufficient and lacking categories. This is a problem for the development of education in North Sumatra Province. In line with this, the Head of the North Sumatra Provincial Education Office must take a more intensive coaching role. Guiding school principals on a regular basis can be done through the work meetings of the principals (MKKS) and also through special meetings held by the Department of Education.

\subsection{Suggestion}

\section{a. Suggestions to Researchers}

- Increasing the variables influencing the variables of work motivation and job satisfaction. 
- Future studies are expected to work on various methods and strategies to improve leadership quality, organizational culture, work motivation, job satisfaction, and performance.

- This research has not seen the influence of each indicator on other indicators so that further research is recommended to analyze the effect of each indicator on other indicators, and what are the best methods and strategies for improving these indicators.

\section{b. Advice to the Principal}

- Improve performance by improving overall indicators that build performance.

- Increase work motivation by increasing overall indicators that build work motivation.

- Increase job satisfaction by increasing overall indicators that build job satisfaction.

- Increasing leadership abilities and competencies that they have.

- Improving the organizational culture that is built up in him by increasing the overall indicators that build organizational culture.

\section{c. Advice to the Office of Education}

- The Head of the North Sumatra Provincial Education Office must supervise education for school principals in order to improve the performance of school principals.

- The Head of the North Sumatra Provincial Education Office should develop programs and training in order to improve leadership, organizational culture, work motivation, job satisfaction, and performance at the head of high schools in Medan.

- The Head of the North Sumatra Provincial Education Office should carry out the control function by means of reward and punishment.

- The Head of the North Sumatra Provincial Education Office should carry out the recruitment of school principals with good selection and in accordance with the criteria and indicators of good school principals.

\section{References}

Ch. Platisa Ch., Reklitisb P., S. Zimerasc. ( 2015 ). Relation between job satisfaction and job performance in healthcare services. Procedia - Social and Behavioral Sciences 175.

Colquitt Jason A., Jeffery A. Lepine, dan Michael J. Wesson. (2009). Organizational Behaviour. Improving Perfomance and Commitment in the Workplace, New York: McGraw-Hill.

Dharma, Surya. 2008. Penilaian Kinerja Kepala Sekolah. Jakarta: Ditjen PMTK Kemendiknas.

Fred E. Fiedler. (1967). Theory of Leadership Effectiveness. New York: McGraw-Hill Book, Company.

Donald Ary, Lucy Cheser Jacobs, dan Asghar Razaveih (1982). Pengantar Penenelitian dalam Pendidikan. Terjemahan Arief Furchan. Surabaya: Usaha Nasioal

Elazar J. Pedhazur, (1982). Multiple Regression in Behavioral Research. Explanation and Prediction. New York: CBS College Publishing.

Emmanuel Ogbonna dan Lloyd C. Harris, "Leadership style, organizational culture and performance: empirical evidence from UK companies", International Journal of Human Resource Management 11:4 August 2000

Hariandja T.E. Marihot. (2005). Manajemen Sumber Daya Manusia. Jakarta: PT Gramedia Widiasarana Indonesia. 
Hersey, P., \& Blanchard, K. H. (1977). Management of Organization Behavior: Utilizing human resources. $3^{\text {rd }}$. Englewood Cliffs, N. J: Prentice Hall, Inc.

James A.F. Stoner. (1992). Manajemen. Edisi kedua, Terjemahan Agus Maulana dkk. Jakarta: Penerbit Erlangga.

John A. Wagner dan John R. Hollenberg, (2010). Organizational Behaviour. Securing Competitive Advantage. New York : Routledge.

Mangkunegara Prabu Anwar. (2005). Perilaku dan Budaya Organisasi. Bandung: PT Rafika Aditama.

Nawawi, Hadari. (1988). Manajemen Sumber Daya Manusia: Untuk Bisnis yang Kompetitif. Yogyakarta: Gajah Mada University Press.

Newstrom, John W. (2007). Organizational Behavior. Twelfth Edition. Boston: McGraw Hill.

Pangaribuan Wanapri, Siburian Paningkat, Manullang Jongga. Determining Factors of Senior High School Principals' Performance in Medan North Sumatera Indonesia, International Journal of Sciences: Basic and Applied Research (IJSBAR), 2016, Vol. 25, No. 2.

Robbins, Stephen P. (1998). Organizational Behaviour. New Jersey, New York: Prentice Hall International Inc.

Siagian, P. Sondang. (1999). Manajemen Sumber Daya Manusia. Jakarta: Bumi Aksara.

Sonnentag, Sabine. (2012). Psychological Management of Individual Performance. London: John Wiley \& Son Ltd.

Usman, Husaini. 2008. Manajemen Teori: Praktek dan Riset Pendidikan. Jakarta: Bumi Aksara. 